\title{
Comparison between Magnesium Sulphate and Ketorolac Intravenous Infusion on Characteristics of Spinal Anesthesia
}

\author{
AHMED R. EL-REWENY, M.Sc.; ABDELRAHEEM M. DOWIDA, M.D.; GHADA F. EL-BARADEY, M.D. and \\ REHAB S. EL-KALLA, M.D.
}

The Department of Anesthesiology and Surgical ICU, Faculty of Medicine, Tanta University

\begin{abstract}
Background: Spinal anesthesia is used widely for many procedures, many adjuvants had been used to prolong duration of sensory and motor block and improve post-operative pain.

Aim of Study: The aim of this study is to compare the effect of magnesium sulphate and ketorolac intravenous infusion on sensory and motor blockage, hemodynamic parameters, duration of analgesia and side effects during spinal anesthesia.

Patients and Methods: Patients were classified randomly into three groups (30 patients each) Group M (Magnesium sulphate Group), Group K (Ketorolac Group), Group C (Control Group). Group M patients received a loading dose of magnesium sulphate $40 \mathrm{mg} / \mathrm{kg}$ IV over $10 \mathrm{~min}$ followed by $15 \mathrm{mg} / \mathrm{kg} / \mathrm{h}$ IV infusion, Group K patients received a loading dose of ketorolac $(0.4 \mathrm{mg} / \mathrm{kg})$ (IV) over $10 \mathrm{~min}$ followed by $0.8 \mathrm{mg} / \mathrm{kg} / \mathrm{h}$ IV infusion. Group C received $50 \mathrm{ml}$ of saline (IV) over 10min followed by saline infusion. After ensuring free flow of cerebrospinal fluid, $3 \mathrm{~mL}$ of bupivacaine $(0.5 \%)$ injected Pulse rate, electrocardiography, non-invasive blood pressure and $\mathrm{SpO}_{2}$ monitored continuously. Measurements: Demographic data (age, weight, BMI, ASA physical status). Hemodynamic (HR, MAP, $\mathrm{SpO}_{2}$ ) before giving study drugs, 10 min after giving study drugs and after reaching the maximal level of spinal anesthesia and then every $30 \mathrm{~min}$ till end of surgery. Onset of sensory blockade has been assessed by pinprick method. Onset of motor blockade has been assessed by modified Bromage Scale. Level of sensory and motor blockade has been checked at 3,5,10 and $15 \mathrm{~min}$ after spinal anesthesia and then every $20 \mathrm{~min}$ throughout the surgery. Time to achieve complete regression from sensory and motor blockade has been noted. All the durations were calculated considering the time of spinal injection as zero time. Postoperatively analgesia has been assessed by the Visual Analog Scale (VAS). The time at which analgesia was first received and total analgesic requirement in $24 \mathrm{~h}$ was recorded. Patients observed for any adverse effects such as nausea, hypotension.

Results: There were insignificant changes between the three groups in HR and MAP but there was significant decrease in HR and MAP in each group at 10min, maximal level and 30min in comparison with base line.
\end{abstract}

Correspondence to: Dr. Ahmed R. El-Reweny, The Department of Anesthesiology and Surgical ICU, Faculty of Medicine, Tanta University
There were insignificant changes in onset and duration of sensory and motor block in the three studied groups.

The total dose of analgesic consumption (pethidine (mg)) showed significant decrease in Group $\mathrm{M}$ in comparison with Group K \& Group C with insignificant change between Group K \& Group C.

The time of first rescue analgesia showed significant increase in Group M in comparison with Group K \& Group $\mathrm{C}$ and insignificant changes in Group $\mathrm{K}$ in comparison with Group C.

Conclusion: Addition of intravenous magnesium sulphate with spinal anaesthesia provides significant decrease in postoperative analgesic requirements and prolongs the time of the first rescue analgesia as compared to intravenous ketorolac with spinal anaesthesia.

Key Words: $\begin{aligned} & \text { Spinal anesthesia - Magnesium Sulphate - } \\ & \text { Ketorolac. }\end{aligned}$
-

\section{Introduction}

SPINAL anesthesia is used widely for patients undergoing urological procedures, lower abdominal and lower limb surgery. Different adjuvant such as morphine, fentanyl, midazolam and clonidine had been used to prolong spinal anesthesia, providing the possible advantages of the better pain control in the early post-operative period and reduced deep vein thrombosis [1]

Magnesium is the fourth most essential ion in the human body and plays an important role in many cellular functions, such as storage, metabolism, and energy utilization. Magnesium has been reported to produce important analgesic effects including the suppression of neuropathic pain, potentiating of morphine analgesia, and attenuation of morphine tolerance. Although the exact mechanism is not yet fully understood, the analgesic properties of magnesium are believed to stem 
from regulation of calcium influx into the cell and antagonism of N-Methyl-D-Aspartate (NMDA) receptors in the central nervous system and inhibition of catecholamine release $[2,3]$

Ketorolac is a non-steroidal agent with potent analgesic and moderate anti-inflammatory activity, it is used for management of moderate to severe pain. Ketorolac is not associated with respiratory depression, nonspecific COX inhibition may lead to gastric mucosal affection, platelet activity affection and renal insult but these effects are dose and duration dependent [4]

Recently it has been suggested that IV magnesium sulphate and IV ketorlac may affect spinal anesthesia efficiency [5].

\section{Patients and Methods}

This prospective, randomized, double-blind comparative study was carried out in Tanta University Hospital from March 2017 to March 2018.

After approval from Institutional Ethics Committee (approval code number 53244), an informed written consent was taken from each patient. Every patient received an explanation to the purpose of the study and a secret code number to ensure privacy to participants and confidentiality of data. Research results were only used for scientific purposes. Any unexpected risk appears during the course of the research was cleared to the participants and Ethical Committee on time and proper measures was taken to overcome or minimize these risks. Ninety patients aged between 18 and 60 years, ASA I \& II, scheduled for lower abdominal, urological and lower limb surgeries were enrolled into the present study.

Patient refusal, patients with known hypersensitivity or contraindications to local anesthetic or study drugs, patients with history of sleep apnea, obesity (BMI >30), myopathy or neuromuscular disease, patients with second or third degree heart block, patients with hepatic and renal dysfunction, psychiatric illness and any contraindication to spinal anesthesia were excluded from the study.

Patients were classified randomly into three groups (30 patients each) Group M (Magnesium sulphate Group), Group K (Ketorolac Group), Group C (Control Group), pre-operative assessment was done to all patients and they were preloaded with injection of Ringer lactate $(10 \mathrm{ml} / \mathrm{kg})$. On arrival to operation room, patients medicated with study drugs. Group M patients received a loading dose of magnesium sulphate $40 \mathrm{mg} / \mathrm{kg}$ IV over $10 \mathrm{~min}$ followed by $15 \mathrm{mg} / \mathrm{kg} / \mathrm{h}$ IV infusion, Group $\mathrm{K}$ patients received a loading dose of ketorolac $(0.4 \mathrm{mg} / \mathrm{kg})(\mathrm{IV})$ over $10 \mathrm{~min}$ followed by 0.8 $\mathrm{mg} / \mathrm{kg} / \mathrm{h}$ IV infusion. Group C received $50 \mathrm{ml}$ of saline (IV) over 10min followed by saline infusion. Lumbar puncture performed at the level of L3L4/L4-L5 space with 23/25-gauge spinal needle. After ensuring free flow of cerebrospinal fluid, $3 \mathrm{~mL}$ of bupivacaine $(0.5 \%)$ injected Pulse rate, electrocardiography, non-invasive blood pressure and $\mathrm{SpO} 2$ monitored continuously. Oxygen delivered by an oxygen mask $(5 \mathrm{~L} / \mathrm{min})$ to all patients throughout procedure.

Measurements: Demographic data (age, weight, BMI, ASA physical status). Hemodynamic (HR, MAP, $\mathrm{SpO} 2$ ) before giving study drugs, $10 \mathrm{~min}$ after giving study drugs and after reaching the maximal level of spinal anesthesia and then every $30 \mathrm{~min}$ till end of surgery. Onset of sensory blockade has been assessed by pinprick method. Onset of motor blockade has been assessed by modified Bromage Scale. Level of sensory and motor blockade has been checked at 3,5,10 and $15 \mathrm{~min}$ after spinal anesthesia and then every $20 \mathrm{~min}$ throughout the surgery. Time to achieve complete regression from sensory and motor blockade has been noted. All the durations were calculated considering the time of spinal injection as zero time. Postoperatively analgesia has been assessed by the Visual Analog Scale (VAS). The time at which analgesia was first received and total analgesic requirement in $24 \mathrm{~h}$ was recorded. Patients observed for any adverse effects such as nausea, hypotension.

\section{Results}

There was no statistical significant difference between study groups as regards to demographic data (age, sex, BMI, ASA physical status) (Table $1)$.

There was insignificant changes between the three groups in HR and MAP but there was significant decrease in HR and MAP in each group at $10 \mathrm{~min}$, maximal level and 30min in comparison with base line (Tables 2,3).

There were insignificant changes in onset and duration of sensory and motor block in the three studied groups (Table 4).

The total dose of analgesic consumption [pethidine $(\mathrm{mg})]$ showed significant decrease in Group 
M in comparison with Group $\mathrm{K} \&$ Group $\mathrm{C}$ with insignificant change between Group K \& Group C.

The time of first rescue analgesia showed significant increase in Group M in comparison with
Group $\mathrm{K}$ \& Group $\mathrm{C}$ and insignificant changes in Group K in comparison with Group C (Table 4).

There was insignificant difference in bradycardia, hypotention and nusea \& vomiting in study groups.

Table (1): Demographic data of the three studied groups.

\begin{tabular}{llllll}
\hline & Group M & Group K & Group C & Test & $p$-value \\
\hline $\begin{array}{l}\text { Age (years): } \\
\text { Range }\end{array}$ & $20-48$ & $20-58$ & $19-57$ & F: & 0.804 \\
$\quad$ Mean \pm SD & $33.60 \pm 7.11$ & $34.97 \pm 9.44$ & $34.70 \pm 8.74$ & 0.219 & \\
Sex: & & & & & \\
$\quad$ Male (\%) & $19(63.3 \%)$ & $17(56.7 \%)$ & $17(56.7 \%)$ & $\chi^{2}:$ & 0.832 \\
Female $(\%)$ & $11(36.7 \%)$ & $13(43.3 \%)$ & $13(43.3 \%)$ & 0.367 & \\
BMI $\left(\mathrm{kg} / \mathrm{m}^{2}\right):$ & & & & & \\
$\quad$ Range & $18-24.5$ & $18.2-25$ & $18-25$ & $\mathrm{~F}:$ & 0.872 \\
Mean $\pm \mathrm{SD}$ & $21.04 \pm 1.85$ & $21.09 \pm 1.95$ & $21.30 \pm 2.23$ & 0.137 & \\
ASA: & & & & & \\
I $(\%)$ & $17(56.7 \%)$ & $16(53.3 \%)$ & $15(50 \%)$ & $\chi^{2}:$ & 0.875 \\
II $(\%)$ & $13(43.3 \%)$ & $14(40.7 \%)$ & $15(50 \%)$ & 0.268 & \\
\hline
\end{tabular}

Table (2): Onset of motor and sensory block ( $\mathrm{min})$ time of motor and sensory block (min) total dose of analgesic requirements [mg (pethidine)] and time of first rescue analgesia (hr.) in the three studied groups.

\begin{tabular}{|c|c|c|c|c|c|}
\hline & Range & Mean \pm SD & F.Test & $p$-value & \\
\hline \multicolumn{6}{|c|}{ Onset of sensory block ( $\mathrm{min})$ : } \\
\hline Group M & $2-4.5$ & $3.37 \pm 0.74$ & 0.256 & 0.775 & \\
\hline Group K & $2-4.5$ & $3.40 \pm 0.77$ & & & \\
\hline Group C & $2-5$ & $3.50 \pm 0.74$ & & & \\
\hline \multicolumn{6}{|c|}{ Onset of motor block ( $\mathrm{min})$ : } \\
\hline Group M & $3-6$ & $4.37 \pm 0.83$ & 0.117 & 0.890 & \\
\hline Group K & $3-5.5$ & $4.32 \pm 0.61$ & & & \\
\hline Group C & $3-6$ & $4.42 \pm 0.93$ & & & \\
\hline \multicolumn{6}{|c|}{ Duration of motor block (min): } \\
\hline Group M & $74-92$ & $81.43 \pm 4.88$ & 1.712 & 0.187 & \\
\hline Group K & $69-88$ & $78.80 \pm 6.17$ & & & \\
\hline Group C & $70-90$ & $80.87 \pm 6.25$ & & & \\
\hline \multicolumn{6}{|c|}{ Duration of sensory block (min): } \\
\hline Group M & $123-150$ & $135.97 \pm 7.72$ & 1.778 & 0.175 & \\
\hline Group K & $120-150$ & $133.73 \pm 9.06$ & & & \\
\hline Group C & $120-140$ & $132.17 \pm 6.56$ & & & \\
\hline \multicolumn{6}{|c|}{ Total analgesic requirement $(\mathrm{mg})$ : } \\
\hline Group M & $40-120$ & $71.67 \pm 18.30$ & 13.638 & $0.001 *$ & $p_{1} 0.002 *$ \\
\hline Group K & $75-160$ & $95.50 \pm 29.87$ & & & $p_{2} 0.001 *$ \\
\hline Group C & $70-165$ & $110.67 \pm 36.38$ & & & $p_{3} 0.052$ \\
\hline \multicolumn{6}{|c|}{ Time of first rescue analgesia $(h r)$ : } \\
\hline Group M & $2-5$ & $3.37 \pm 0.71$ & 33.418 & $0.001 *$ & $p_{1} 0.001 *$ \\
\hline Group K & $1-4$ & $2.70 \pm 0.70$ & & & $p_{2} 0.001 *$ \\
\hline Group C & $1-3$ & $1.88 \pm 0.70$ & & & $p_{3} 0.061$ \\
\hline
\end{tabular}

$p$ 1: Group M \& Group K.

p2: Group M \& Group C

p3: Group K \& Group C. 


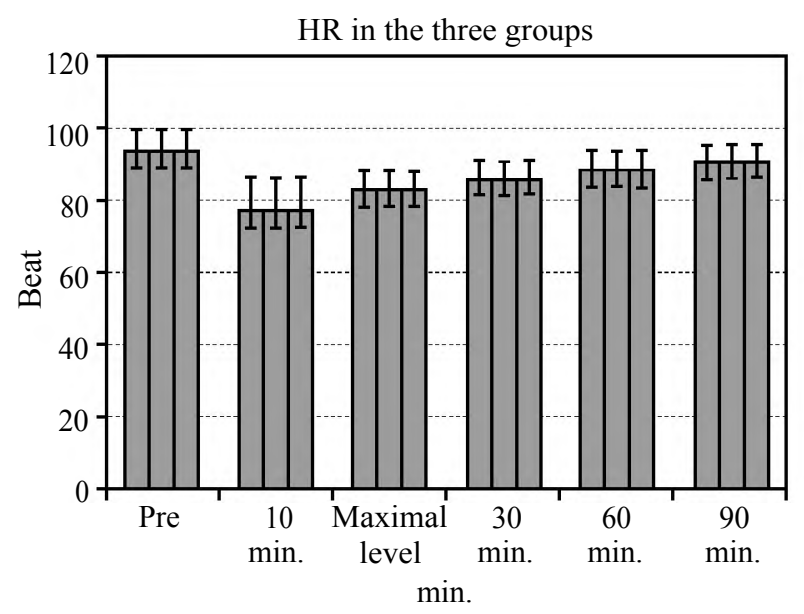

Fig. (1): Comparison between heart rate (beat $/ \mathrm{min}$ ) changes in the three studied groups.

\section{Discussion}

Various systemic and Intrathecal adjuvants are combined with LAs in order to potentiate the spinal block and prolong analgesia [6]. They allow reduction of the LA dose [7], thus enables faster recovery of motor function and voiding, with elimination of side effects associated with larger doses and consequently a faster discharge $[8]$

As regard demographic data and patient characteristics, there was no significant difference between the three studied groups.

Concerning hemodynamic changes after giving study drugs, mean arterial blood pressure \& HR showed significant decrease at $10 \mathrm{~min}$, maximal level of spinal anesthesia and 30min after induction of spinal anaesthesia and insignificant changes at $60 \mathrm{~min}, 90 \mathrm{~min}$ in the three study groups with insignificant changes between the three study groups, so no effect of magnesium sulphate or ketorolac on hemodynamics was encountered.

Magnesium causes a dose-dependent negative inotropic effect, and in humans haemodynamic studies have shown that it has a peripheral (predominantly arteriolar) vasodilatory effect. After rapid infusion of 3 or $4 \mathrm{~g}$ of magnesium sulphate, systolic arterial pressure decreased in relation to decreased systemic vascular resistance [9] in the present study, considering the negative intropic effect of $\mathrm{Mg}$, prehydration with $10 \mathrm{ml} / \mathrm{kg}$ of lactated Ringer's solution was performed and the $\mathrm{Mg}$ bolus dose was infused over $10 \mathrm{~min}$, which is probably why no significant hypotension was encountered after administering the $\mathrm{Mg}$ bolus dose and no significant inter-group haemodynamic differences were observed during the surgery.

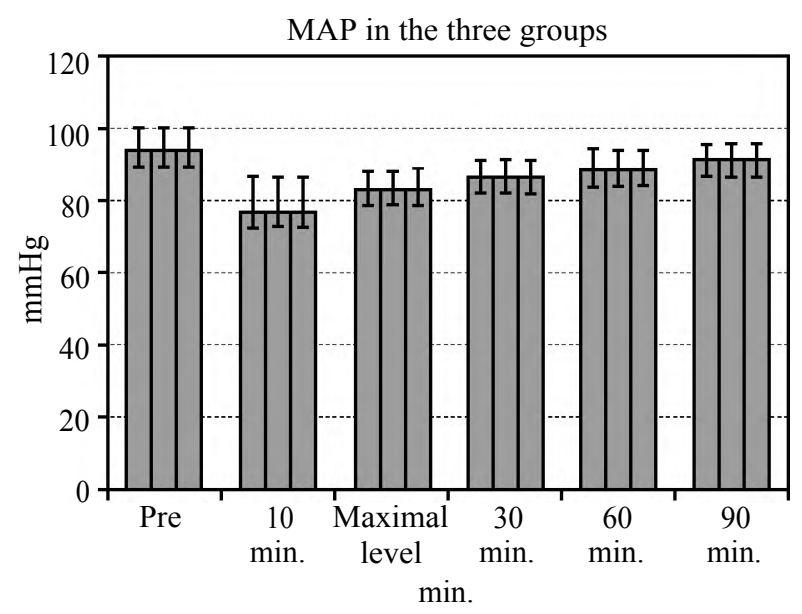

Fig. (2): Mean Arterial blood Pressure (MAP) changes in the three studied groups.

Ketorolac has analgesic properties through direct anti-inflammatory effects. Moreover, ketorolac neither causes respiratory depression, nor other side-effects such as vomiting, itching, and hemodynamic instability, but it has some gastrointestinal and antiplatelet effects [10].

In agreement with our results Kumar M et al., 2013 [11]. Studied the effect of intravenous magnesium sulphate on post-operative pain following spinal anesthesia. Patients were given either $\mathrm{MgSO}_{4}$ $50 \mathrm{mg} / \mathrm{kg}$ in $10 \mathrm{~mL}$ within $10 \mathrm{~min}$, followed by an infusion of $\mathrm{MgSO}_{4} 10 \mathrm{mg} / \mathrm{kg} / \mathrm{hr}$. IV in $4 \mathrm{~mL}$ (MG group) for $12 \mathrm{hrs}$. or normal saline in same volume and rate for $12 \mathrm{hrs}$. After initiating the infusion, spinal anesthesia was given. they reported that hemodynamic variability did not differ from the control group.

Also, Shah P.N 2016 [12] . In their study they assessed the hemodynamic effects of intravenous magnesium sulfate and rescue analgesia requirement with spinal anesthesia patients received either $250 \mathrm{mg}$ of intravenous magnesium sulfate followed by an infusion of $500 \mathrm{mg}$ magnesium sulfate $(25 \mathrm{mg} /$ $\mathrm{mL}$ ) at the rate of $20 \mathrm{~mL} /$ hour; or the same volume of normal saline (control group) as bolus and infusion they were in line with our results as they noticed insignificant fall of MAP \& HR. In this study the doses was lower than our study but in both studies no effect on MAP and HR was observed.

In contrast to our study Sebastian S.K et al., 2015 [13] in their study on perioperative Magnesium sulphate infusion with spinal anaesthesia. 'M' Group for magnesium and 'S' group for placebo. ' $\mathrm{M}$ ' Group was infused with $500 \mathrm{ml}$ normal saline containing Magnesium sulphate at a dose of $8 \mathrm{mg} / \mathrm{kg} / \mathrm{hr}$. till 
the end of the surgery. The placebo Group 'S' also received same amount of normal saline till the end of surgery. There was increase in hypotension in M Group 36.7\% compared to placebo.

In addition Albrecht E et al., 2013 [5] in their study Peri-operative intravenous administration of magnesium sulphate and postoperative pain: A meta-analysis. Twenty-five trials comparing magnesium with placebo were identified. They found that bradycardia was more common in magnesium group.

In ketorolac group, our results were in agreement with those of Khezri M.B et al., 2018 [14] In their study on one hundred and fifty patients who were scheduled for elective cesarean section under spinal anesthesia were randomly allocated to one of three study groups to receive intravenous ketorolac (Group K), meperidine (Group M) or normal saline (Group P). They found that there was hemodynamic stability as these drugs can prevent high blood pressure and tachycardia by decreasing anxiety, fear and pain.

To the best of our knowledge we didn't find any study suggested that ketorolac infusion affect MAP \& HR.

As regards the onset, duration and level of sensory and motor block, our results showed no significant difference between the three groups.

As regard Group $\mathrm{M}$ our results were in agreement with Kumar M et al., 2013 [11] found that magnesium infusion with spinal anaesthesia has no effect on onset, duration and level of sensory and motor block between studied groups.

Also, Hwang J.Y et al., 2010 [15] in their study I.V. infusion of magnesium sulphate during spinal anaesthesia improves post-operative analgesia they foud no effect of magnesium on the level of bupivacaine induced sensory block or the duration of spinal analgesia.

In contrast to our study Shah P.N et al., 2016 [12] found that intravenous magnesium sulfate prolongs the duration of sensory and motor blockade of spinal anesthesia.

As regard Group $\mathrm{K}$ we didn't find significant effect of ketorolac infusion on onset, duration and level of sensory and motor block. To the best of our knowledge this is the first study on the effect of ketorolac infusion on characteristics of spinal anaesthesia.
As regarding total analgesic requirement and time of first rescue analgesia Group $M$ had delayed 1 st analgesic requirement and had the least total consumption of rescue analgesia compared to Group K and Group C and there were no diffrence between Group K compared to Group C.

As regard Group $\mathrm{M}$ our results were in agreement with Shah P.N. et al., 2016 [12] who concluded that the use of intravenous $\mathrm{Mg}$ with spinal anesthesia delayed and decreased the need of rescue analgesics after spinal anesthesia.

Also Albrecht E et al., 2013 [5] found that perioperative magnesium can provide a clinically important reduction in opioid consumption.

Moreover, Hwang J.Y et al., 2010 [15] found that magnesium sulphate given i.v. during spinal anaesthesia reduced post-operative pain and analgesic consumption without complications.

In contrast to our study, Ko et al., 2001 [16] reported that administering magnesium in patients undergoing abdominal hysterectomy $50 \mathrm{mg} / \mathrm{kg}$ in the pre-operative period and $15 \mathrm{mg} / \mathrm{kg} / \mathrm{h}$ intraoperatively and $6 \mathrm{~h}$ after the operation had no effects on post-operative pain.

Also Tramer M.R et al., 2007 [17], in their study on patients undergoing ambulatory ilioinguinal hernia repair or varicose vein operations supplemented with other analgesic adjuvants, pretreatment with IV magnesium sulfate $4 \mathrm{~g}$ has no impact on post-operative pain and analgesic consumption.

As regard Group K our results were in agreement with Beatriz et al., 2017 [18], in their study No preemptive analgesic effect of pre-operative ketorolac administration following total abdominal hysterectomy: A randomized study. Patients in the ketorolac group received $30 \mathrm{mg}$ of IV ketorolac $30 \mathrm{~min}$ before surgical incision, while the control group received normal saline. There was no difference in pain intensity between the two groups the time to first rescue analgesia and the total analgesic consumption were similar.

Our results were in disagreement with Khezri M.B et al., 2018 [14]. They found that preemptive prescription of a single dose of intravenous ketorolac can effectively reduce severity of post-operative pain and prolong the time of first rescue analgesia.

Regarding side effects in our study, there were insignificant difference among three groups. 
In agreement with our results Kumar M et al., 2013 [11] found that the incidence of bradycardia, hypotension, nausea and vomiting was insignificant in patients received IV magnesium sulphate.

Also Shah P.N 2016 [12] found that incidence of bradycardia, hypotension, nausea and vomiting in patients received IV magnesium sulphate was insignificant.

In contrast to our results Sebastian S.K et al., 2015 [13] found that hypotension was significantly increased in patient received IV magnesium sulphate.

Also Albrecht E et al., 2013 [5] found that bradycardia was significantly increased with IV magnesium sulphate.

As regard Ketorlac Nistal N.B et al., 2018 [14] found that the incidence of bradycardia, hypotension, nausea and vomiting was insignificant in patients received IV, ketorolac.

\section{Conclusion:}

Addition of intravenous magnesium sulphate with spinal anaesthesia provides significant decrease in post-operative analgesic requirements and prolongs the time of the first rescue analgesia as compared to intravenous ketorolac with spinal anaesthesia.

Based on this study we recommend administration of IV bolus (40mg/kg) and infusion $(15 \mathrm{mg} /$ $\mathrm{kg} / \mathrm{hr}$ ) of magnesium sulphate with spinal anaesthesia, it is safe to use; it improves post-operative analgesia and reduces analgesic requirement without having any effect on onset and recovery from spinal anesthesia.

\section{References}

1- QIU M.T., LIN F.Q., FU S.K., ZHANG H.B., LI H.H., ZHANG L.M., et al.: Combination of Low Dose Bupivacaine and Opioids Provides Satisfactory Analgesia with Less Intraoperative Hypotension for Spinal Anesthesia in Cesarean Section. CNS Neurosci Ther., 18 (5): 42632, 2012.

2- FERIA M., ABAD F., SANCHEZ A. and ABREU P.: Magnesium sulphate injected subcutaneously suppresses autotomy in peripherally deafferented rats. Pain, 53 (3): 287-9, 1993.

3- McCARTHY R.J., KROIN J.S., TUMAN K.J., PENN R.D. and IVANKOVICH A.D.: Antinociceptive potentiation and attenuation of tolerance by intrathecal coinfusion of magnesium sulfate and morphine in rats. Anesth. Analg., 86 (4): 830-6, 1998.
4- GILLIS J.C. and BROGDEN R.N.: Ketorolac: A reappraisal of its Pharmacodynamic and Pharmacokinet Propertis and Therabutic Use in Pain Management. Drugs, 53 (1): 139-88, 1997.

5- ALBRECHT E., KIRKHAM K., LIU S. and BRULL R.: Peri-operative intravenous administration of magnesium sulphate and post-operative pain: A meta-analysis. Anaesthesia, 68 (1): 79-90. 81, 2013.

6- PAN P., HUANG C., WEI T. and MOK M.: Enhancement of analgesic effect of intrathecal neostigmine and clonidine on bupivacaine spinal anesthesia. Regional Anesthesia and Pain Medicine, 23 (1): 49-56, 1998.

7- ORTNER C., POSCH M., ROESSLER B., FAYBIK P. RÜTZLER K., GRABOVICA J., et al.: On the ropivacaine-reducing effect of low-dose sufentanil in intrathecal labor analgesia. Acta Anaesthesiol. Scand., 54 (8): 1000-6, 2010

8- FASSOULAKI A., SARANTOPOULOS C. and ZOTOU M.: Nitrous oxide enhances the level of sensory block produced by intrathecal lidocaine. Anesth. Analg., 85 (5): 1108-11, 1997.

9- RYU J.H., SOHN I.S. and DO S.H.: Controlled hypotension for middle ear surgery: A comparison between remifentanil and magnesium sulphate. Br. J. Anaesth., 103 (4): 490-5, 2009.

10- SOSTRES C., GARGALLO C.J., ARROYO M.T. and LANAS A.: Adverse effects of non-steroidal antiinflammatory drugs (NSAIDs, aspirin and coxibs) on upper gastrointestinal tract. Best practice \& research Clinical Gastroenterology, 24 (2): 121-32, 2010.

11- KUMAR M., DAYAL N., RAUTELA R. and SETHI A.: Effect of intravenous magnesium sulphate on postoperative pain following spinal anesthesia. A randomized double blind controlled study. Middle East J. Anesthesiol., 22 (3): 251-6, 2013.

12- SHAH P.N. and DHENGLE Y.: Magnesium sulfate for post-operative analgesia after surgery under spinal anesthesia. Acta Anaesthesiologica Taiwanica, 54 (2): 624, 2016.

13- SEBASTIAN S.K., ABRAHAM V., RAJKUMAR A. and JACOB L.: A study on peri-operative magnesium sulphate on post-operative pain management in patients undergoing pelvic and lower limb surgeries. Journal of Evolution of Medical and Dental Sciences, 4 (2): 228-42, 2015.

14- KHEZRI M.B., MOSALLAEI M.A.S., EBTEHAJ M. and MOHAMMADI N.: Comparison of preemptive effect of intravenous ketorolac versus meperidine on post-operative shivering and pain in patients undergoing cesarean section under spinal anesthesia: A prospective, randomized, double-blind study. Caspian J. Intern. Med., 9 (2): 151, 2018.

15- HWANG J.Y., NA H.S., JEON Y.T., RO Y.J., KIM C.S. and DO SH.: I.V. infusion of magnesium sulphate during spinal anaesthesia improves post-operative analgesia. Br. J. Anaesth., 104 (1): 89-93, 2010.

16- KO S.H., LIM H.R., KIM D.C., HAN Y.J., CHOE H. and SONG H.S.: Magnesium sulfate does not reduce postoperative analgesic requirements. Anesthesiology, 95 (3): 640-6, 2001. 
17- TRAMER M.R. and GLYNN C.J.: An evaluation of a single dose of magnesium to supplement analgesia after ambulatory surgery: Randomized controlled trial. Anesth. Analg., 104 (6): 1374-9, 2007.
18- NISTAL-NUNO B.: No preemptive analgesic effect of preoperative ketorolac administration following total abdominal hysterectomy: A randomized study. Saudi J. Anaesth., 11 (2): 169-76, 2017.

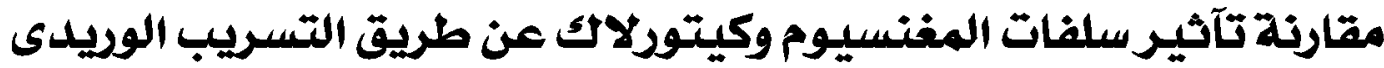

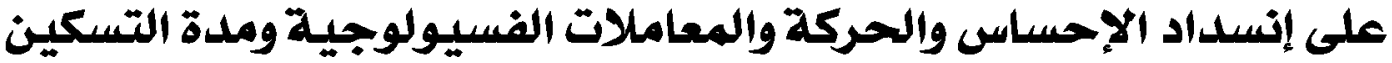

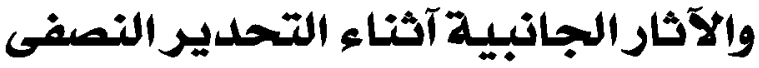

المقدمة: يعد التخدير النصفى من آكثر الطرق شيوعاً. حيث يعتبر التخدير النصفى داخل الآم العنكبوتية من آفضل الوبسائل لتسكين آلام

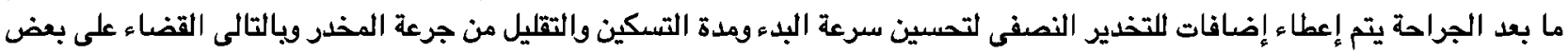

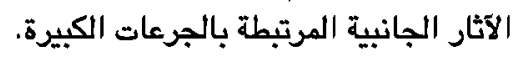

وقد إستخدمت كل من كبريتات المغنسيوم عن طريق المقن في المديد، الميدازولام، الكيتامينو مضادات الإلتهاب غير الستيرتيدية لهذا الغرض.

الهدف من البحث: الهدف من هذه الدراسة مقارنة تآثير سلفات المغنسيقم وكيتودلاك عن طريق التسريب الوديدى على إنسداد الإحساس

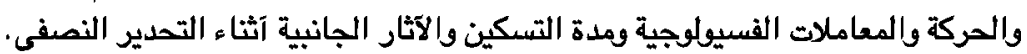

المرضى وطرق البحث: تم إجراء هذه الدراسة على .9 مريضاً من الجنسين طبقاً لتصنيف الجمعية الآمريكية لآطباء التخدير مجهزين لعمل جراحات آسفل البطن والآطراف السفلية والمسالة البولية. آسباب الإستبعاد من الدراسة: • تم إستبعاد المرضى الذين لديهم موانع التخدير النصفى.

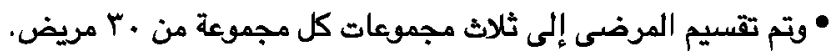
مجموعة M (سلفات المغنسيوم): بعد الوصول إلى غرفة العمليات المجموعة الآولى سوف يتم حقن جرعة هن سلفات المغنسيوم ، عملجم لكل كجم في مدة قدرها ـ ـ دقائق تتبع بجرعة هامجم/كجم في الساعة عن طريق التنقيط الوديلهي. مجموعة K (كيتور لاك):

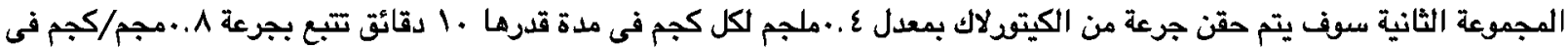
الساعة عن طريق التنقيط المديدى. مجموعة Can (محلول ملح): والمجموعة الثالثة سوف يتم حقن • مملل من محلول ملح فى مدة ـ 1 دقائق تتبع بمحلول ملح عن طريق التقيط الوديدى. متابعة القياسـات الحيوية آثاء العملية: تم متابعة ضغط الدم والنبض ورسم القلب، كما تم متابعة حدوث آى نوبات من القئ آو الرعشة. القياسات التى تم تسبجيلها: ا- البيانات الديمغرافية (العمر، الونن، مؤشر كتلة الجسم، تصنيف الجمعية الآمريكية للتخدير للحالة الجسمانية). Y- متوبسط ضغط الدم ومعل النبض ونسبة آكسجين الدم قبل إعطاء عقاقير الدراسة وبعد ـ1 دقائق من إعطائها وبعد ذلك كل .ب دقيقة حتى نهاية العملية الجراحية. r- بداية تآثر الإحساس. ع- بداية تآثر الخواص الصركية. 


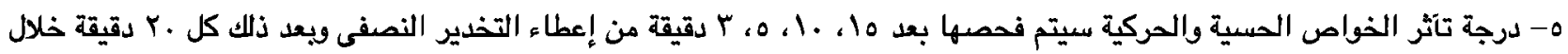
العملية الجراحية وسوف يتم تسجيل الوقت الذى يحدث عنده إنصسار كامل للإنسداد الصسى والحركي.

$$
\text { 1- سوف تحسب جميع المدل بإعتبار وقت حقن العمود الفقرى كالساعة صفر. }
$$

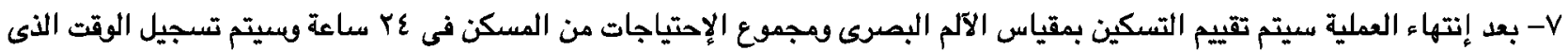

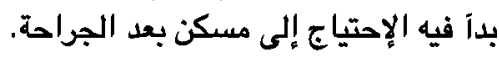

النتائج: وقد آظهرت نتائج الدراسة وجوف تغيرات ليست ذات قيمة بين المجموعات الثلاثة في معدل النبض ومتوبط ضغط الدم لكنه تم

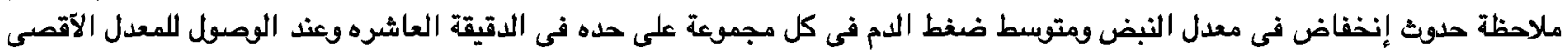
من التخدير النصفى وعند الدقيقة الثلاثن. معن.

وقد كانت هناك تغييرات ليست ذات قيمة في درجة تآثّر الخواص الحسية والحركية بين الثلاث مجموعات. ولكن لوحظ آن المجموعة M لم تحتاج إلى جرعة كبيرة من الآدوية المسكنة بعد الجراحة مقارنة بالمجموعتين K و C كما آن الوقت اللازم

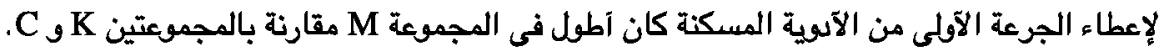

الخلاصة": إضافة سعات المغنسيوم عن طريق التقيظ الوريدى لحالات التخدير النصفى يزيد من مدة تسكين الآلم ما بعد الجراحة ويقلل

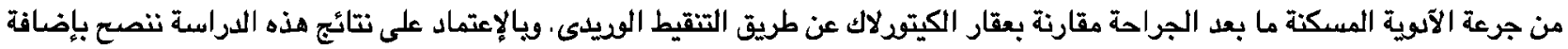

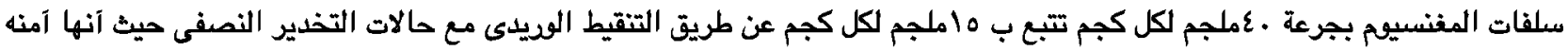

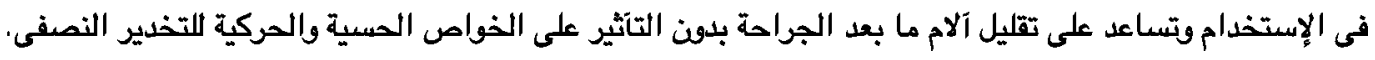

